\section{Botanists' blues}

\author{
Nature's Palette: The Science of \\ Plant Color \\ by David Lee \\ University of Chicago Press: 2007. 384 pp \\ $\$ 35$
}

\section{Philip Ball}

"Why grass is green, or why our blood is red, Are mysteries which none have reach'd into." John Donne's words were true in the seventeenth century. Today they certainly aren't, as David Lee makes clear in Nature's Palette, an enchanting survey of colour in plants. Among the mysteries is why some plants are electric blue, such as Selaginella, a relative of ferns that thrives in the rainforests of Malaysia. Its leaves are as blue as some butterfly wings, and for the same reason: it is a 'structural' colour, produced by light scattered from a periodic banded microstructure in the outer cell walls. The shaded undergrowth of the forests is home to several other blue-leafed plants, but it's not clear why they should reflect so much light when it's such a scarce commodity. After 30 years of looking, Lee still has no good explanation.

Blue leaves abound in seventeenth-century Dutch flower and landscape paintings. One of the most striking examples is Adam Pynacker's Landscape with Sportsmen and Game, in which a garish clump of blue foliage on the gloomy woodland floor appears every bit as surreal as Selaginella. This is not a botanical oddity, however, nor is it what the artist intended. Over time the yellow pigment in the green mixture has faded. But there is a botanical explanation, as painters commonly used yellow pigments from plant extracts, such as saffron or weld, that are damaged by light. Plants require merely a seasonal burst of exuberant advertising, so their pigments don't last - as generations of artists and dyers have found to their cost.

Dutch flower paintings also depict tulips streaked with feathery white. These 'broken tulips' appear unpredictably among otherwise identical bulbs, and are short-lived and hard to propagate. As a result, they were so rare in Baroque Holland that it was often cheaper to hire a painter to capture their beauty than to acquire a bulb. Speculators bought thousands of bulbs in the hope of finding a few such variants that would sell for a fortune, creating the infamous 'tulip mania', the archetypal economic bubble driven by speculation. As Lee explains, we know now that the broken tulips were diseased, infected by a virus that interferes with pigment production.

Lee's book is packed with many such gems from botanical and social history. So captivating is his passion for botany that his occasionally bewildering thickets of carotenes and anthocyanins can be forgiven. His paean provides a compelling case that botany is full of intellectual challenges, many shamefully neglected. He shows, for example, that plants are extraordinary biological devices, with leaves that act as arrays of lenses or mobile light antennaes, or that change colour on exposure to light, thanks to the mobility of their chloroplasts. But only one Nobel prize has ever been awarded for fundamental biological research on plants - for Barbara McClintock's discovery of transposons in maize, which had to weather a storm of scepticism before being rewarded.

Like its subject, the book can be overwhelmingly heady. A scary glimpse into the hothouse world of Miami orchid breeding suggests there is a lurid thriller waiting to be written on the subject by Carl Hiaasen. And the cloying scents of the 'gallant south', evoked so unforgettably in the Billie Holiday song Strange Fruit, are all the more palpable for knowing that some flower odours mimic rotting carcasses to attract carrion flies. So obsessive is the flower-lover's demand for novelty that a biotech company, Florigene, set itself up with the sole mission of making blue roses and carnations. A jackpot awaits if they succeed, but I can't help thinking the romance will be well and truly lost on the way. Philip Ball is a consultant editor of Nature.

\title{
What do mathematicians do?
}

\section{How Mathematicians Think: Using \\ Ambiguity, Contradiction, and \\ Paradox to Create Mathematics \\ by William Byers \\ Princeton University Press: 2007. 425 pp. $\$ 35$ \\ The Mathematician's Brain: A Personal Tour Through the Essentials of Mathematics and Some of the Great Minds Behind Them \\ by David Ruelle \\ Princeton University Press: 2007. 176 pp. $\$ 22.95$ \\ The Mind of the Mathematician by Michael Fitzgerald \& loan James Johns Hopkins University Press: 2007. 312 pp. $\$ 30$}

\section{Donal O'Shea}

Mathematics is a corpus of immutable, rigorously established facts, right? Wrong. Three recent books argue that mathematics is a profoundly human enterprise, best described as what mathematicians do.
In the most ambitious, accessible and provocative of the three, How Mathematicians Think, William Byers argues that the core ingredients of mathematics are not numbers, structure, patterns or proofs, but ideas. Numbers are ideas, and so are functions and even logic. Ideas are organizing principles. They are neither right nor wrong.

The polymath Arthur Koestler famously characterized ambiguity as involving a single situation or idea that is perceived in two selfconsistent but mutually incompatible frames of reference. Mathematics thrives on ideas that harness ambiguity. Byers maintains that great ideas, like Simone Weil's notion of 'true good', have conditions that are contradictory and so seem impossible - they encapsulate ambiguity that is so great as to seem paradoxical.

There's ambiguity everywhere. Zero, for instance, captures both the notion of nothingness, or absence, and the idea that nothing is something. 89/17 signifies both a number and the operation of dividing 89 by 17 . Algebraic expressions such as $3 x+2$ represent a process (take a number, multiply it by 3 and add 2 ) and a set of numbers. The variable $x$ in an

\section{On the Surface of Things}

by Felice Frankel and George M. Whitesides (Harvard Univ. Press, $\$ 24.95, E 16.95$ )

A handsome re-issue of Felice Frankel's startling photography reveals the extraordinary beauty of chemical surfaces. Roald Hoffmann wrote: "One holds in one's hands an obvious classic at the nexus of art and science" (Nature 389, 348; 1997).

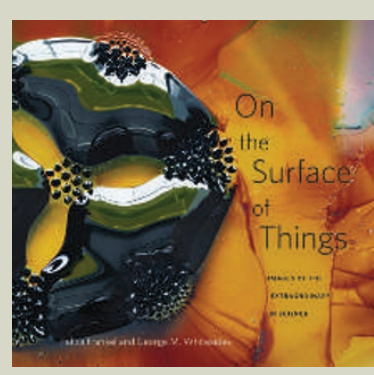

The Intelligibility of Nature: How Science Makes Sense of The World by Peter Dear (Univ. Chicago Press, \$17) Science historian Peter Dear shows how the twin objectives of 'doing' and 'knowing' gave rise to modern science as a means of understanding the world. "Scientists who wish to reflect on their vocation will gain valuable insights from this beautifully contrived book" (Richard Yeo, Nature 445, 820-821; 2007).

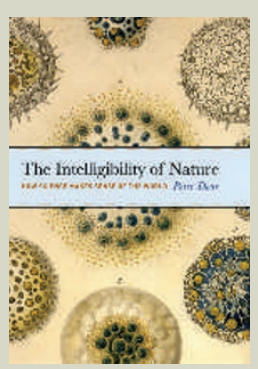

